\title{
Keanekaragaman Arthropoda dan Intensitas serangan pada Tanaman Cabai (Capsicum Annum L,) Di Desa Tanjung Pering Kecamatan Indralaya Utara
}

\author{
Arsi $^{1 *}$, Andika Tiara Sukma ${ }^{2}$, Kevin Christian BP ${ }^{3}$, M. Rafii $F^{4}$, Fitra Gustiar ${ }^{5}$, Irmawati ${ }^{6}$, \\ Suparman $\mathrm{SHK}^{7}$, Harman Hamidson ${ }^{8}$, Yulia Pujiastuti ${ }^{9}$, Bambang Gunawan ${ }^{10}$, Abu \\ Umayah $^{11}$, Nurhayati ${ }^{12}$ \\ *e-mail: arsi@fp.unsri.ac.id

\section{1,2,3,4,7,8,9,10,11,12 Program Studi Proteksi Tanaman, Fakultas Pertanian Univeristas Sriwjaya 5,6Program Studi Agroekoteknologi, Fakultas Pertanian Univeristas Sriwjaya}

\begin{abstract}
Red chili (Capsicum annum L,) is one of the important vegetables with high economic value and is suitable to be developed in the tropics. The cultivation of red chili has long been intensively cultivated by farmers and is a source of income and job opportunities that contribute quite high to regional economic development. Cultivation of red chili many obstacles faced by farmers, namely, pest and disease attacks. The purpose of this study was to determine the diversity of arthropods and the intensity of pest attacks on chili plantations. This insect observation method uses the Scan sampling method, Pantrap, Yellowtrap and the intensity of insect attacks. The data is displayed descriptively, tables and figures. Based on the results of visual observations found 4 orders and 8 species that are pests and 3 orders with 4 species that are predators. The species found in the pan trap trap were 4 orders and 15 species with different roles. Yellowstcikytrap traps were found in 6 orders and 15 species with various roles in chili cultivation. Arthropod diversity in chili cultivation varies. Insects that damage chili plants are aphids (Aphis gossypii), whitefly (Bemisia tabaci) and fruit flies (Bactrocera spp.) which have different levels of damage on each land.
\end{abstract}

Keywords: Arthropods, chilies, insect pests and attack intensity

\begin{abstract}
ABSTRAK
Cabai merah (Capsicum annum $\mathrm{L}$,) merupakan salah satu jenis sayuran penting yang bernilai ekonomis tinggi dan cocok untuk dikembangkan di daerah tropika. Budidaya cabai merah telah lama diusahakan oleh petani secara intensif dan di merupakan sumber pendapatan serta kesempatan kerja yang memberikan kontribusi cukup tinggi terhadap perkembangan ekonomi daerah. Budidaya cabai merah banyak kendala yang dihadapi petani yaitu, serangan hama dan penyakit. Tujuan penelitian ini untuk mengetahui keanekaragaman arthropoda dan intensitas serangan hama pada pertanaman cabai. Metode pengamatan serangga ini dengan menggunakan metode Scan sampling, Pantrap, Yellowtrap dan intensitas serangan serangga. Data-data tersebut ditampilkan secara deskritip, tabel dan gambar. Berdasarkan hasil pengamatan secara visual ditemukan 4 ordo dan 8 spesies yang bersifat sebagai hama serta 3 ordo dengan 4 spesies yang bersifat sebagai predator. Spesies yang ditemukan pada perangkap pantrap terdapat 4 ordo dan 15 spesies dengan berbeda peranan. Perangkap Yellowstcikytrap ditemukan 6 ordo dan 15 spesies yang bervariasi peranannya di pertanaman cabai. Keanekaragaman arthropoda pada pertanaman cabai bervariasi. Serangga yang merusak pada tanaman cabai yaitu Kutu daun (Aphis
\end{abstract}


gossypii), Kutu kebul (Bemisia tabaci) dan Lalat Buah (Bactrocera spp.) yang memiliki tingkat kerusakan yang berbeda pada masing-masing lahan.

Kata Kunci: Arthopoda, cabai, serangga hama dan Intensitas serangan

\section{PENDAHULUAN}

Cabai merah (Capsicum annum L.) merupakan salah satu jenis sayuran penting yang bernilai ekonomis tinggi dan cocok untuk dikembangkan di daerah tropika seperti di Indonesia (Rante dan Manengkey, 2017). Berdasarkan data dari Badan Pusat Statistik (2015), luas panen cabai memiliki peringkat tertinggi dibandingkan dengan sayuran lainnya, selain itu dilihat dari jumlah produksinya, cabai juga merupakan sayuran yang memiliki produksi tertinggi di Indonesia, secara nasional tingkat produktivitas cabai merah selama lima tahun terakhir mencapai 6 ton/hektar (Eliyatiningsih dan Mayasari, 2019). Menurut data Badan Pusat Statistik (2020), tanaman sayuran cabai diproduksi oleh seluruh wilayah di Sumatera Selatan yang terdiri dari 13 Kabupaten dan 4 Kotamadya. Prakiraan pertumbuhan jumlah produksi tanaman sayuran cabai di Provinsi Sumatera Selatan pada tahun 2020 meningkat sebesar 196,407 kuintal (38,14\%) sedangkan untuk tahun 2021 tumbuh sebesar 56,71\% dari tahun 2019 (Hatta dan Nursanty, 2020).

Usahatani cabai merah telah sejak lama diusahakan oleh petani secara intensif, Komoditas ini juga merupakan sumber pendapatan dan kesempatan kerja yang memberikan kontribusi cukup tinggi terhadap perkembangan ekonomi daerah, apalagi harga cabai merah yang selama beberapa tahun terakhir mengalami kenaikan yang signifikan. Nilai ekonomis yang tinggi pada produk cabai merah telah membuat komoditas ini diusahakan hampir di semua provinsi di Indonesia (Eliyatiningsih dan Mayasari, 2019).

Banyak kendala yang dihadapi petani dalam budidaya cabai yaitu Organisme Penggangu Tanaman seperti gangguan hama dan penyakit (Agustinawati et al., 2016; Harmana dan Rahardjo, 2021), beberapa hama penting yang umumnya menyerang tanaman cabai yaitu ulat grayak Spodoptera litura Fabricius (Arsi dan Kemal, 2021; Cahyono et al., 2018), kutu daun Myzus persicae Sulzer, Aphis gossypii Glover (Anggraini, 2018; Candra et al., 2020; Manikome, 2018; Yasurruni, 2018), lalat buah Bactrocera dorsalis Hendel (Budiyani dan Sukasana, 2020; Hasibun, 2020; Juniawan, 2020; Sari et al., 2020; Solihin, 2020; et al., 2021). trips Thrips parvispinus Karny (Intarti et al., 2020; Rante dan Manengkey, 2018; Yulia et al., 2021: Nur et al., 2017) dan tungau Tetranychus telarius (Saroinsong, 2014). Produktivitas buah yang rendah dan waktu panen yang lama tentunya akan memperkecil rasio keuntungan petani cabai (Rizqullah dan Syamsuddin, 2020), Sampai saat ini belum terformulasi langkah yang tepat untuk penanggulangannya, Oleh sebab itu diperlukannya inovasi teknologi pengendalian OPT pada tanaman cabai merah secara integrasi, salah satu diantaranya adalah dengan menerapkan teknologi Pengendalian Hama Terpadu (PHT) (Setiawati et al,, 2013; Susanto et $a l .$, ). Keanekaragaman arthropoda yang ada di lapangan harus diketahui peranannya masing-masing dipertanaman, sehingga keberadaannya arthropoda tersebut dapat dijadikan untuk pengendalian hama yan merusak tanaman (Jasridah et al., 2021; Putra dan Utami, 2020; Yulia et al., 2021). Tujuan penelitian ini untuk mengetahui keanekaragaman arthropoda dan intensitas serangan hama pada pertanaman cabai. 


\section{BAHAN DAN METODE}

Penelitian ini dilaksanakan di lahan cabai merah milik petani yang ada di Desa Tanjung Pering, Kecamatan Indralaya Utara, Kabupaten Ogan Ilir (Gambar 1).

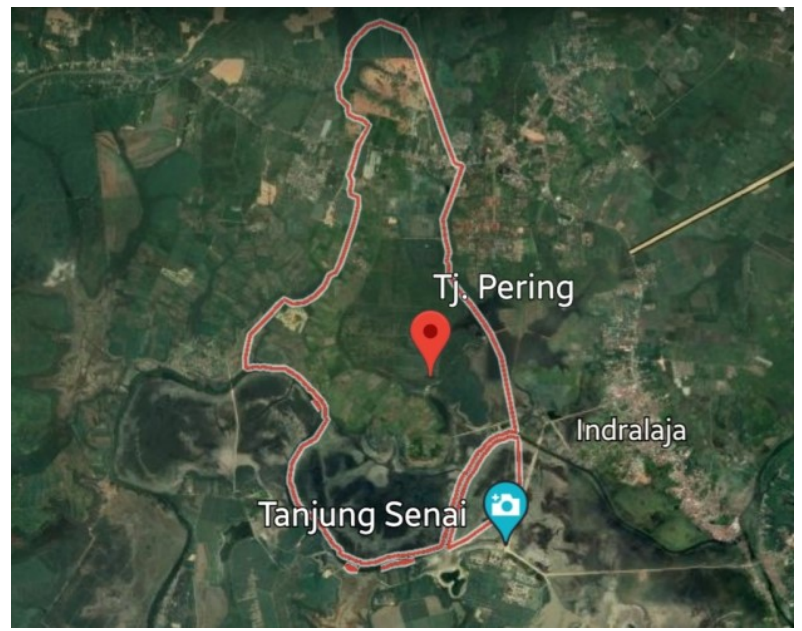

Gambar 1. Peta lokasi penelitian tanaman cabai di Desa Tanjung Pering

Adapun alat yang digunakan pada praktek lapangan ini adalah : 1) ATK, 2) Kamera, Adapun bahan yang digunakan pada praktek lapangan ini adalah : 1) Hama yang diamati, 2) Tanaman Cabai, Penelitian ini dilakukan dengan metode survey 10 lahan cabai yang ada di Desa Tanjung Pering dan metode pengamatan dilakukan secara langsung (Scan sampling) dengan mengamati intesitas serangan dan jumlah populasi, Observasi adalah salah satu teknik yang dilakukan untuk melihat dan mengamati populasi serta gejala serangan hama pada tanaman cabai, sehingga diperlukan sebagai acuan untuk melakukan penelitian lebih lanjut, Wawancara ini dilaksanakan dengan cara melakukan percakapan langsung dan tanya jawab, Wawancara ini dilakukan dengan pemilik lahan atau petani tersebut dan juga bagaimana cara petani melakukan budidaya pada lahan tersebut serta alasan dalam memilih tanaman,

Pengambilan lahan dengan melakukan survei ke beberapa lahan milik petani tanaman cabai di Desa Tanjung Pering, Kecamatan Indralaya Utara, dengan luas lahan yang berbeda. Cara menentukan tanaman sampel dilakukan dengan cara menghitung jumlah guludan yang ada dilapangan, kemudian untuk mengambil sampel tanaman digunakan dengan metode Purposive Sampling dan di ambil 5 guludan atau 5 titik dengan masingmasing satu guludan 10 sampel tanaman dan berjumlah \pm 50 tanaman cabai perlahan.

\section{Pembuatan dan Pemasangan Perangkap Yellowtrap dan Pantrap}

Pada pembuatan perangkap yellowtrap memerlukan beberapa bahan diantaranya yaitu cat kayu berwarna kuning, papan triplek, kuas, kayu ring, paku, stepler, dan lem lalat, Pertama papan triplek tersebut dibuat dengan ukuran persegi panjang kemudian di warnai dengan warna kuning, setelah papan triplek selesai, hal selanjutnya adalah beli kayu ring dengan ukuran 4 meter yang dipotong menjadi 12 bagian dengan masing-masing berukuran $60 \mathrm{~cm}$, lalu paku papan triplek tersebut di kayu penyanggah, Perangkap Yellowtrap yang dipakai dibagian papannya diberi lem lalat agar serangga terbang menempel pada bagian tersebut kemudian pasang Yellowtrap di antara tanaman cabai 
masing-masing pada setiap lahan yaitu 5 perangkap, lalu tunggu selama 24 jam, Untuk pembuatan perangkap Pantrap bahan yang digunakan adalah nampan persegi panjang, map berwarna kuning, air, dan sabun, Pembuatannya yang pertama siapkan nampan sebanyak 12 buah, letakkan map kuning yang telah di potong dan di tempel double tip sesuai ukuran dalam nampan, setelah itu isi nampan tersebut dengan air yang telah dicampur sabun, Pantrap yang dibuat diletakkan di antara tanaman, setiap lahan adalah 5 perangkap, Setiap perangkap dipasang pada 10 lahan yang diamati untuk Yellowtrap maupun Pantrap (Gambar 2).

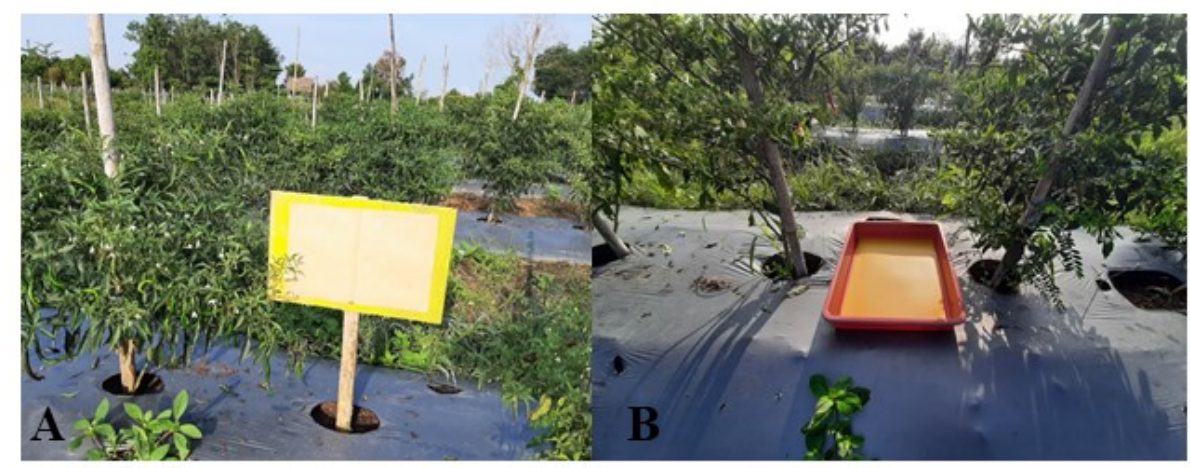

Gambar 2. Perangkap Yellowtrap (A) dan Pantrap (B) pada lahan cabai merah

Pengamatan dilakukan setiap 1 kali pada setiap lahan pukul 07.00 WIB dengan menghitung jumlah populasi dan intesitas serangan hama yang ada dilapangan, Intensitas serangan digunakan untuk melihat tingkat serangan yang ada dilapangan dengan menggunakan skor, Tingkatan skor yang digunakan adalah:

$0 \quad$ : Tidak ada gejala

$1 \quad: 25-50 \%$ Gejala ringan

$2 \quad: 50 \%$ Gejala sedang

$3 \quad: 75 \%$ Gejala berat

$4 \quad: 100 \%$ Gejala sangat berat

Intensitas serangan dihitung dengan rumus berikut:
Persentase intensitas serangan dapat dihitung berdasarkan gejala dengan rumus sebagai berikut:

$$
\text { IS } \left.=\left\{\sum \text { ni } \times \text { vi }\right) /(Z \times N)\right\} \times 100 \%
$$

Keterangan:

IS = Intensitas Serangan (\%)

ni = banyaknya tanaman yang menunjukkan skor ke i

$\mathrm{vi} \quad=$ skor tanaman ke $\mathrm{i}$

$\mathrm{N} \quad=$ Jumlah tanaman yang diamati

$\mathrm{Z}=$ Nilai skala kerusakan tertinggi,

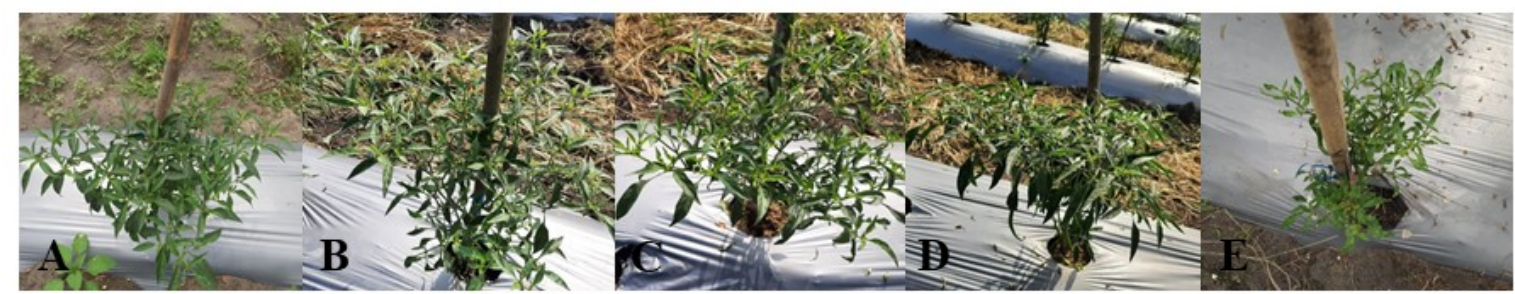

Gambar 3. Penentuan skor serangan hama Kutu daun pada tanaman cabai, gejala serangan hama skor 0 (A), gejala serangan hama skor 1 (B), gejala serangan hama skor 2 (C), gejala serangan hama skor 3 (D), gejala serangan hama skor 4 (E) 


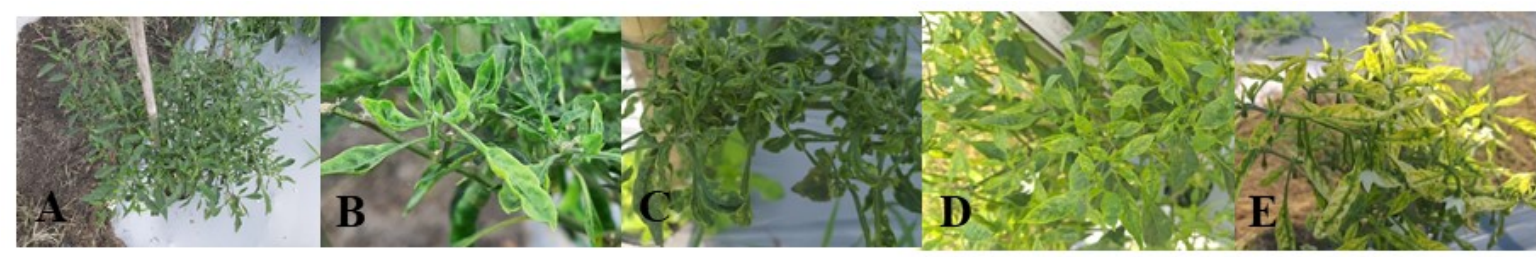

Gambar 4. Penentuan skor serangan hama Kutu kebul (Bemisia tabaci) pada tanaman cabai, gejala serangan hama skor 0 (A), gejala serangan hama skor 1 (B), gejala serangan hama skor $2(\mathrm{C})$, gejala serangan hama skor $3(\mathrm{D})$, gejala serangan hama skor $4(\mathrm{E})$

\section{Analisis Data}

Data hasil pengamatan pada penelitian ini disajikan dalam bentuk Gambar, Grafik dan Tabel. Data yang sudah diperoleh kemudian dianalisis deskriptif dan disajikan dalam bentuk table. Dengan menggunakan rumus Tingkat Keanekaragaman (H'), Sebaran Individu Tiap Spesies (E), Proporsi mendominasi (D).

Tingkat Keanekaragaman, untuk menganalisis spesies dan populasi serangga dilahan percobaan, dihitung keanekaragaman spesies dengan rumus Shannon-Weiner (Magurran, 2014),

$$
H^{t}=-\Sigma \rho \mathbf{i n} \rho \mathbf{j}
$$

Keterangan:

$\mathrm{H}^{\prime}=$ Indeks Shannon

$\mathrm{S}=$ Jumlah Spesies

ni $=$ Jumlah Individu Spesies ke-i

$\mathrm{N}=$ Jumlah individu Semua Spesies

Sebaran Individu dari Setiap Spesies yaitu, untuk menghitung jumlah total individu yang tersebar dalam setiap spesiesnya digunakan Indeks Pieluo (Magurran, 2014):

$$
\mathbf{E}=\mathbf{H}^{\prime} / \text { In S }
$$

Keterangan :

$\mathrm{E}=$ Indeks Pieluo

$\mathrm{H}^{\prime}=$ Indeks Keanekaragaman Shannom

$\mathrm{S}=$ Jumlah Spesies

Proporsi spesies yang paling melimpah (mendominasi) di suatu tempat ditentukan dengan menggunkan rumus indeks Berger-Parker (Magurran, 2014):

$$
\mathbf{d}=\mathbf{N} \max / \mathbf{N}
$$

$\mathrm{d}=$ Indeks Berger-Parker

$\mathrm{N} \max =$ Jumlah Individu yang Paling Dominan

$\mathrm{N} \quad=$ Jumlah Total Individu Semua Spesies

\section{HASIL DAN PEMBAHASAN}

Berdasarkan hasil pengamatan secara visual dilapangan pada penelitian ditemukan 4 ordo, yang terdiri dari ordo Hemiptera, Homoptera, Lepidoptera, dan Diptera, Sedangkan pada arthropoda predator ditemukan 3 ordo dengan 4 famili yang berbeda, Diketahui juga bahwa indeks keragaman serangga hama pengamatan secara visual adalah 2,03, indeks sebaran individu spesies adalah 0,90 , sedangkan proporso spesies yang Mendominasi (D) adalah 0,21 (Tabel 1). Predator secara visual ditemukan 3 ordo dan 4 famili. Spesies yang paling banyak ditemukan pada lahan cabai yaitu, Coccinela transversalis. Indeks keragaman arthropoda dalah 1,63, indeks sebaran individu spesies adalah 0,89, Proporso spesies yang Mendominasi (D) adalah 0,19. Keanekaragaman predator pada lahan tanaman cabai tergolong rendah (Tabel 2). Berdasarkan hasil penelitian dilakukan keragaman serangga di pertanaman cabai tergolong rendah, hal ini dapat dipengaruhi oleh populasi arthropoda di lapangan (Sanjaya dan Dibiyantoro, 2012),

Keterangan : 
Tabel 1. Spesies dan jumlah serangga hama pada tanaman cabai yang didapat pada pengamatan secara visual pada pertanaman cabai

\begin{tabular}{lllcc}
\hline Ordo & Famili & Spesies & Jumlah & Peran \\
\hline Homoptera & Aphididae & Aphis gossypii & 58 & Hama \\
& Aleyrodidae & Bemisia tabaci & 30 & Hama \\
& Ciccadelidae & Empoasca sp, & 20 & Hama \\
Hemiptera & Pentatomidae & Nezara viridula & 20 & Hama \\
& Coreidae & Leptocorisa acuta & 10 & Hama \\
& & Leptoglossus sp, & 16 & Hama \\
Lepidoptera & Noctuidae & Spodoptera litura & 15 & Hama \\
Diptera & Tephritidae & Bactrocera spp, & 25 & Hama \\
\hline Jumlah total semua spesies & & & 194 & \\
\hline Jumlah spesies tertinggi & & & 58 & \\
\hline Indeks Keragaman (H') & & & 2,03 & \\
\hline Sebaran Individu (E) & & & 0,90 & \\
\hline Indeks dominasi (D) & & & & \\
\hline
\end{tabular}

Tabel 2. Spesies dan jumlah serangga yang didapat dengan menggunakan perangkap Pantrap

\begin{tabular}{lllll}
\hline Ordo & Famili & Spesies & Jumlah & Peran \\
\hline Coleoptera & Coccinellidae & Coccinella transversalis & 155 & Predator \\
& & Epilachna admirabillis & 146 & Predator \\
& Chrysomelidae & Coelophora ineaqualis & 95 & Predator \\
& & Aulachopora similis & 15 & Hama \\
& Cerambycidae & Sybra spp, & 10 & Hama \\
& Cydnidae & Aethus sp, & 6 & Hama \\
Hemiptera & Miridae & Stittocapsus sp, & 8 & Hama \\
& Pentatomidae & Halyomorpha sp, & 10 & Hama \\
& & Nezara viridula & 10 & Hama \\
Diptera & Muscidae & Musca domestika & 14 & Dekomposer \\
& Stratiomydae & Hermetia illucens & 4 & Predator \\
& Dolichopodidae & Condylostyles longicornis & 5 & Penyerbuk \\
Hymenoptera & Formicidae & Pachycondila sp, & 10 & Predator \\
& Megachilidae & Dianthidium sp, & 8 & Penyerbuk \\
& Crabronidae & Oxybelus sp, & 20 & Penyerbuk \\
\hline Jumlah spesies & & & 525 & \\
\hline Jumlah spesies tertinggi & & & 155 & \\
\hline Indeks Keragaman (H') & & & 2,21 & \\
\hline Sebaran Individu (E) & & & 0,91 & \\
\hline Indeks dominasi (D) & & & 0,17 & \\
\hline & & & & \\
\hline
\end{tabular}

Berdasarkan hasil pengamatan yang dilakukan dengan menggunakan perangkap Yellowtrap dengan cara perangkap diberi lem lalat dan didiamkan 
selama 1x24 jam. Ditemukan arthropoda yaitu, terdapat 6 ordo dengan 12 Famili yang berbeda. Diketahui juga bahwa Indeks keragaman serangga pada Tabel 3. Spesies dan jumlah serangga yang didapat dengan menggunakan perangkap Yellowtrap

\begin{tabular}{|c|c|c|c|c|}
\hline Ordo & Famili & Spesies & Jumlah & Peran \\
\hline \multirow[t]{5}{*}{ Diptera } & Muscidae & Musca domestika & 10 & Dekomposer \\
\hline & & Hydrotaea sp, & 8 & Parasitoid \\
\hline & Calliphoridae & Phaemicia sericata & 8 & Hama \\
\hline & Anthomyiidae & Delia $\mathrm{sp}$ & 10 & Hama \\
\hline & Tephritidae & Bactrocera sp, & 20 & Hama \\
\hline \multirow[t]{3}{*}{ Coleoptera } & Coccinellidae & Cycloneda munda & 50 & Predator \\
\hline & & Coelophora ineaqualis & 50 & Predator \\
\hline & & Coccinela transversalis & 80 & Predator \\
\hline \multirow[t]{2}{*}{ Hemiptera } & Coreidae & Leptocorisa acuta & 30 & Hama \\
\hline & Pentatomidae & Nezara viridula & 30 & Hama \\
\hline \multirow[t]{2}{*}{ Hymenoptera } & Aphidae & Trigona sp, & 40 & Penyerbuk \\
\hline & Scoliidae & Colpa sexmaculata & 50 & Penyerbuk \\
\hline \multirow[t]{2}{*}{ Homoptera } & Aleyrodidae & Bemisia tabaci & 100 & Hama \\
\hline & Ciccadelidae & Empoasca sp, & 150 & Hama \\
\hline Odonata & Libelullidae & Orthretum sabina & 1 & Predator \\
\hline Jumlah spesies & & & 637 & \\
\hline Jumlah spesies tertinggi & & & 150 & \\
\hline Indeks Keragaman (H') & & & 1,35 & \\
\hline Sebaran Individu (E) & & & 0,87 & \\
\hline Indeks dominasi (D) & & & 0,45 & \\
\hline
\end{tabular}

Keanekaragaman ada beberapa cara yang digunakan dalam melihat suatu populasi arthropoda serangga yaitu dengan cara visual, menggunakan perangkap Pantrap dan perangkap Yellowsticky trap, Serangga yang terperangkap merupakan serangga yang tertarik terhadap warna kuning, sesuai dengan pernyataan Sunarno (2011) bahwa perangkap warna kuning lebih kontras dan mengkilap, sehingga serangga lebih mudah tertarik, dibandingkan dengan jenis perangkap warna lainnya karena warna kuning memiliki panjang gelombang $610 \mathrm{~nm}$. Berdasarkan hasil pengamatan terhadap kesepuluh lahan tanaman cabai memiliki keanekaragaman arthropoda yang perangkap Yellowstickytrap adalah 2,0, indeks sebaran individu spesies adalah 0,87 dan Proporso spesies yang Mendominasi adalah 0,45 (Tabel 3). bervariasi. Hal ini dikarenakan oleh perilaku petani dalam mengelolah lahan dan pengendalian organisme pengganggu tanaman. Penggunaan pestisida yang terlalu sering dalam menekan OPT di lapangan mempengaruhi keberadaan serangga di lapangan. Arthropoda yang berperan sebagai predator memiliki keanekaragaman yang rendah. Hal tersebut tergantung ada tidaknya mangsa bagi musuh alami tersebut, selain itu faktor lingkungan juga dapat mempengaruhi keanekaragaman arthropoda di lahan pertanaman cabai.

$$
\text { Berdasarkan hasil dari }
$$
pengamatan dan identifikasi secara visual serangga hama pada lahan cabai terdiri dari spesies $A$. gossypii memiliki jumlah 
yang paling tinggi, sedangkan untuk jumlah spesies yang paling sedikit adalah L. acuta. Berdasarkan pengamatan secara langsung atau visual dilapangan ditemukan beberapa hama yang menyerang tanaman cabai di Desa Tanjung Pering diantaranya yaitu, kutu daun (Aphis gossypii), Kutu kebul (Bemisia tabaci), lalat buah (Bactrocera spp,) dan Ulat gerayak (Spodoptera litura) yang merupakan hama utama yang menyerang tanaman cabai. Kutu daun (Aphis gossypii) menyerang pada bagian bawah daun yang dapat menyebabkan keriting daun pada tanaman cabai sehingga tanaman akan menjadi layu, kering dan akhirnya mati. Selain itu, serangan kutu kebul (Bemisia tabaci) yang dapat menyebabkan kuning dan klorosis pada daun cabai, disebabkan oleh rusaknya sel-sel dan jaringan daun akibat serangan pada fase nimfa dan imago. Sehingga dapat menghambat pertumbuhan tanaman, Kutu kebul juga diketahui berperan sebagai vektor penyakit salah satunya yakni Virus kuning pada tanaman cabai sesuai pernyataan. Serangan ulat grayak (Spodoptera litura) diawali dengan memakan daun mulai dari bagian tepi, atas maupun bawah daun, bahkan dapat memakan daun hanya akan menyisahkan tulang daunnya saja, Daun yang dimakan menjadi berlubang sehingga menyulitkan dalam proses fotosintesis, Lalat buah biasanya menyerang pada buah yang berkulit tipis, dengan daging yang lunak, serangan lalat sering ditemukan pada buah yang hampir masak, dicirikan dengan daging buah membusuk dan terdapat larva, Larva akan memakan daging buah sehingga buah menjadi busuk sebelum waktunya masak, Selain hama, ada juga arthropoda predator yang terdapat pada cabai diantaranya Kumbang koksi, Capung, Tomcat dan laba-laba dari Famili Oxyopidae (Gambar $5)$.

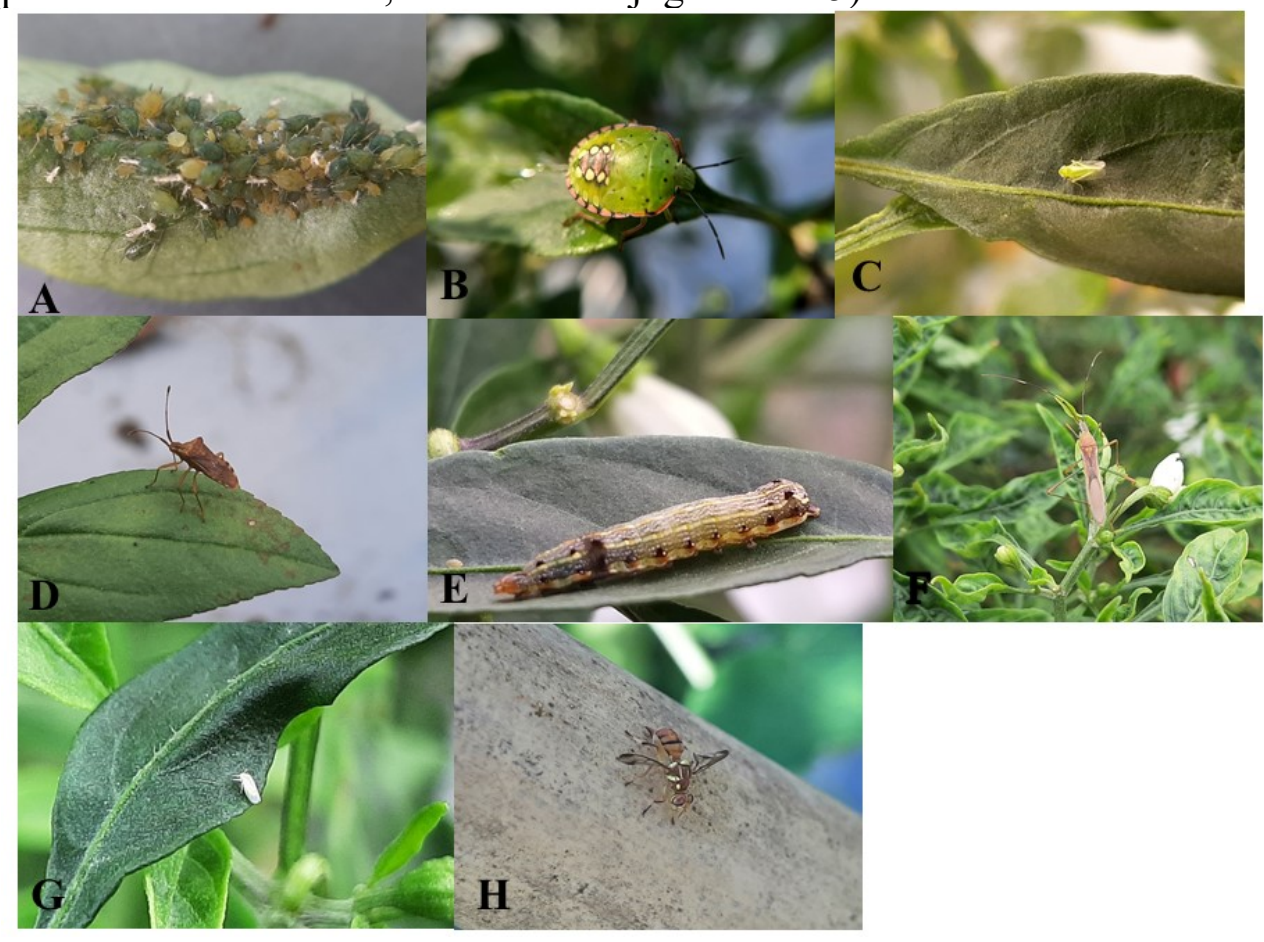

Gambar 5. Beberapa serangga hama pada tanaman cabai yang diamati secara visual, A) Aphis gossypii, B) Hemiptera: Pentatomidae, C) Empoasca sp,, D) Hemiptera : Coreidae, E) Spodoptera litura, F) Leptocorisa acuta, G) Bemisia tabaci, H) Bactrocera spp, 
Berdasarkan hasil pengamatan dan identifikasi secara visual arthropoda predator pada tanaman cabai ditemukan predator dari Famili Coccinellidae memiliki jumlah spesies yang paling tinggi diantara predator yang ditemukan dilapangan, sedangkan untuk jumlah spesies yang sedikit adalah Oxyopes papuanus dari Famili Oxyopidae (Gambar 6).

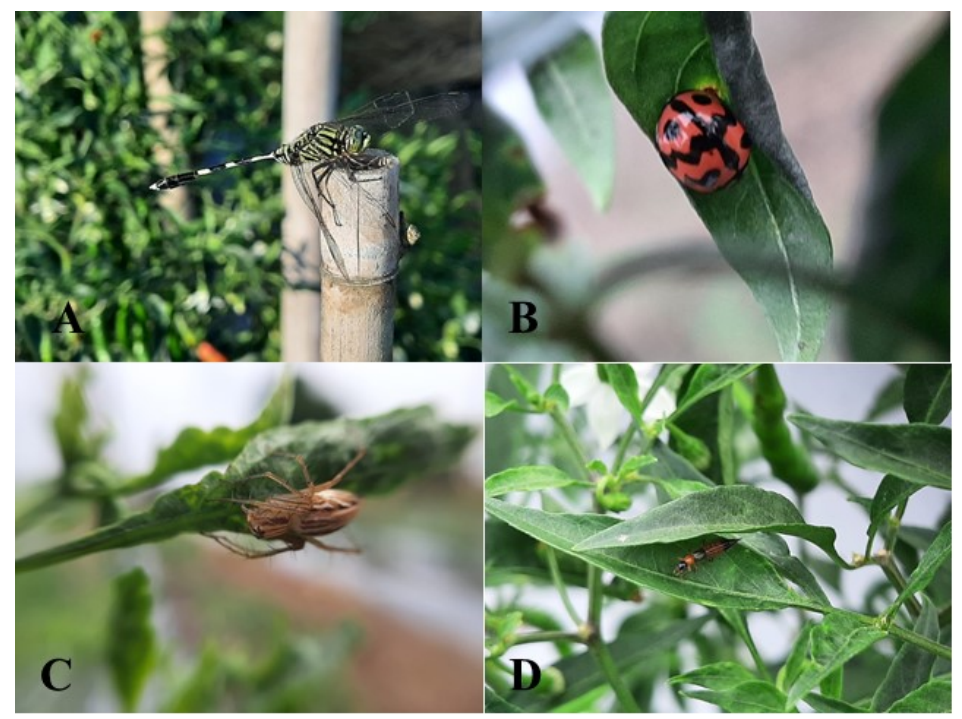

Gambar 6. Arthropoda predator pada tanaman cabai dapat dilihat, A) Orthretum sabina, B) Coccinela transversalis, C) Oxyopes papuanus, D) Paederus fuscipes

Pengamatan serangga dengan menggunakan perangkap Pantrap yang telah didiamkan selama 1 x 24 jam dengan cara mengamati serangga yang masuk kedalam perangkap yang telah diberi warna kuning pada bagian dasar nampan dan diisi air dicampur sabun dan setelah diidentifikasi didapatkan populasi serangga dari kelas insekta keseluruhan berjumlah 525 individu, terdiri dari 4 ordo yaitu Ordo Coleoptera, Hemiptera, Diptera dan Hymenoptera dengan 12 Famili yang berbeda, Serangga yang paling banyak populasinya yang terperangkap adalah dari ordo Coleoptera dari Famili Coccinelidae (Coccinela transversalis) yang berjumlah \pm 155 individu yang berperan sebagai predator sedangkan untuk jumlah serangga yang terendah yakni dari ordo Diptera: Stratiomydae (Hermetia illucens) yang berjumlah 4 individu, dari kesepuluh lahan yang di pasang dan di amati menggunakan perangkap Pantrap di Desa Tanjung Pering (Gambar 7).
Berdasarkan hasil pengamatan serangga dengan menggunakan perangkap Yellowstiky trap yang dipasang selama 1 x 24 jam yang telah diberi perekat pada masing - masing lahan dalam satu petak di pasang 5 perangkap di lahan cabai hasil identifikasi didapatkan populasi serangga dari kelas insekta keseluruhan berjumlah 637 individu, yang terdiri dari 6 ordo yaitu Diptera, Coleoptera, Hemiptera, Hymenoptera, Homoptera dan Odonata dengan 13 famili yang berbeda, Serangga yang paling banyak terperangkap populasinya adalah Empoasca sp, (Homoptera : Ciccadelidae) yang berjumlah 150 individu sedangkan untuk jumlah serangga yang terendah yakni dari ordo Odonata yang berjumlah 1 individu, dari kesepuluh lahan yang di pasang dan di amati menggunakan perangkap Yellowtrap di Desa Tanjung Pering (Gambar 8). 


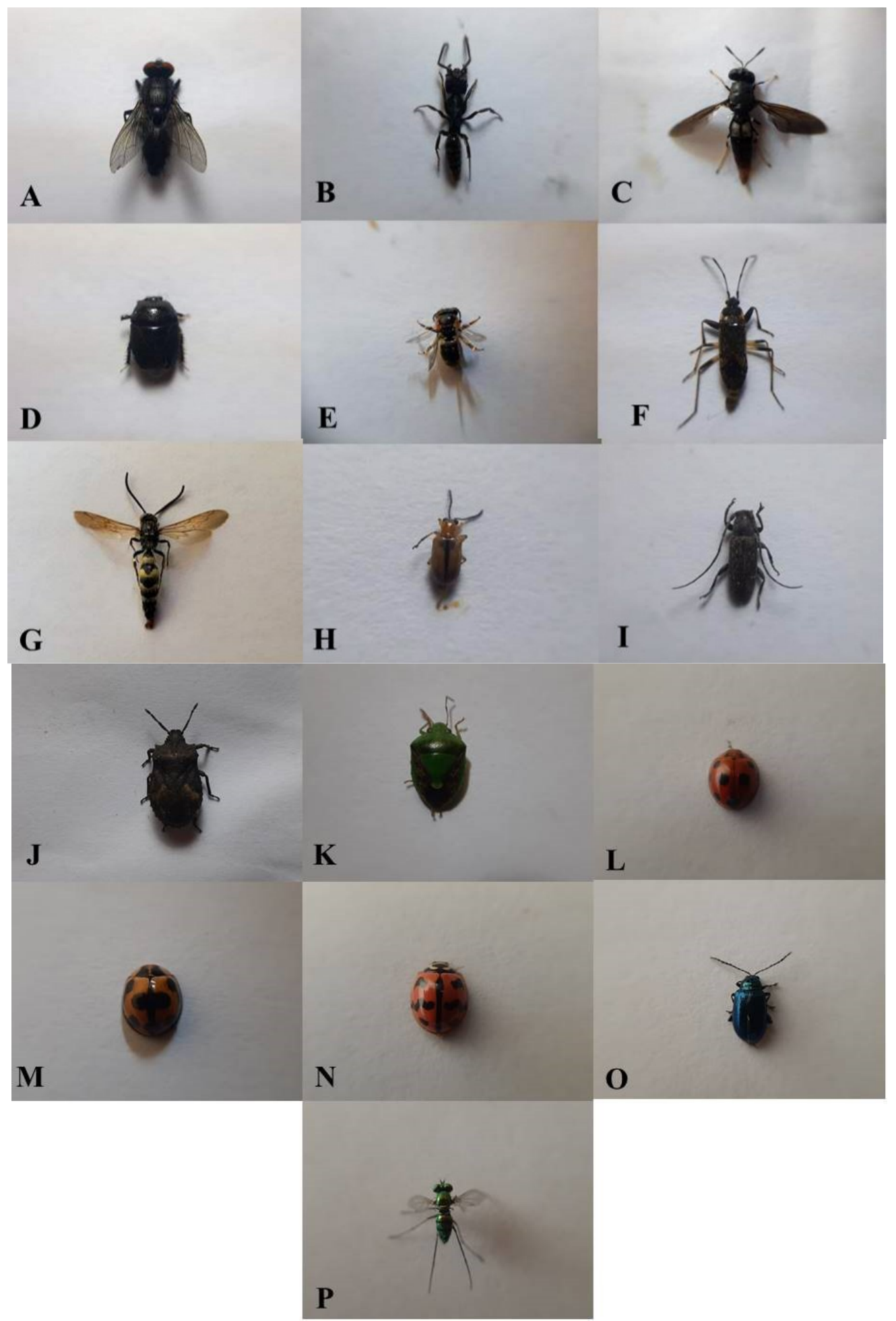

Gambar 7. Hasil pengamatan dan identifikasi serangga dengan menggunakan perangkap pantrap, dapat dilihat pada gambar A) Musca domestica, B) Pachycondyla sp,, C) Hermetia illucens, D) Aethus sp,, E) Dianthidium sp,, F) Stittocapsus sp,, G) Colpa sexmaculata, H) Aulacophora similis, I) Sybra sp,, J) Halyomorpha sp,, K) Nezara viridula, L) Epilachnana admirabilis, M) Coelophora ineaqualis, N) Coccinela transversalis, O) Altica spp,, dan P) Condylostylus longicornis. 


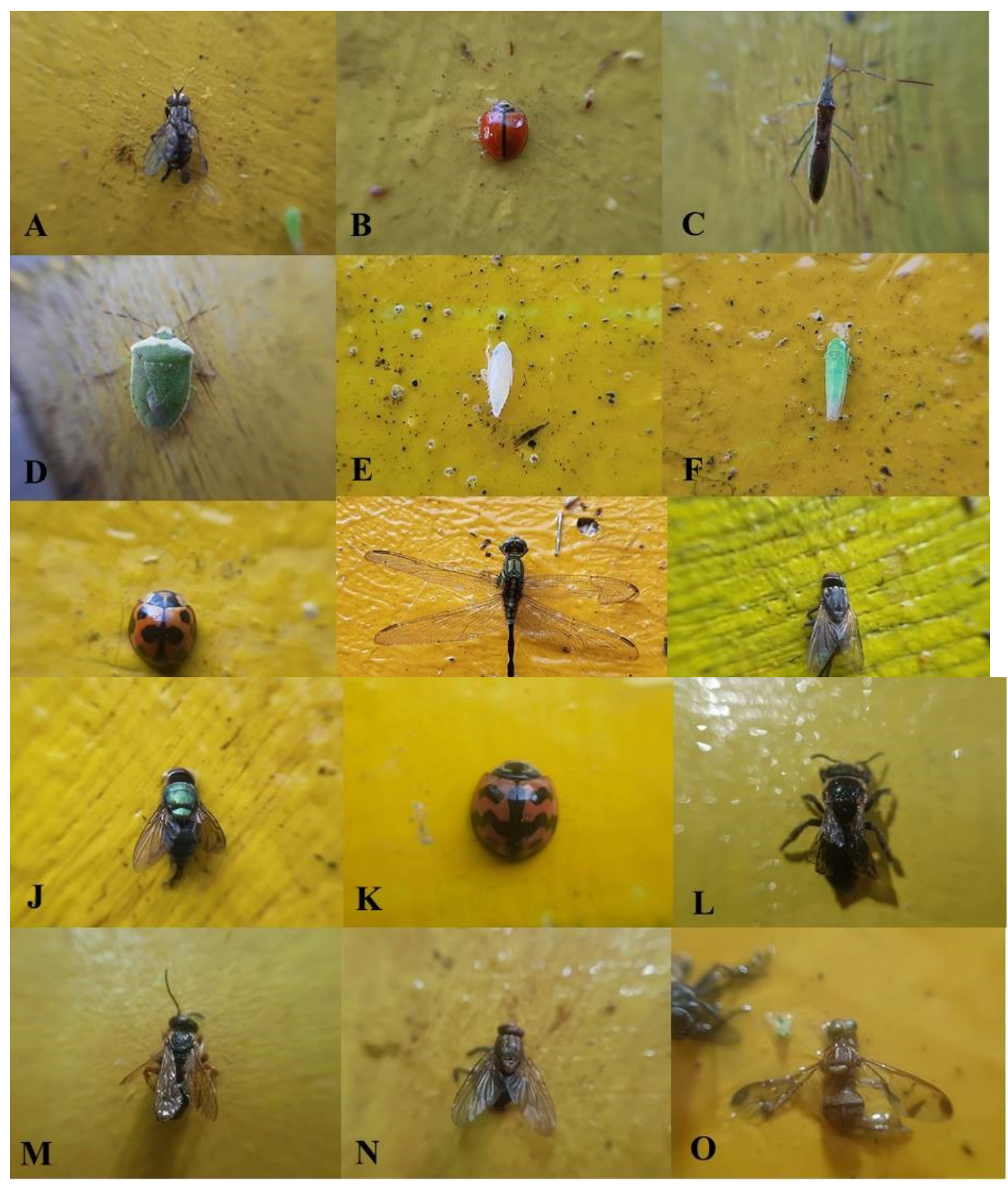

Gambar 8. Hasil pengamatan dan identifikasi serangga dengan menggunakan perangkap Yellowtrap dapat dilihat pada gambar A) Musca domestika, B) Cycloneda munda, C) Leptocorisa acuta, D) Nezara viridula, E) Bemisia tabaci, F) Empoasca sp., G) Coelophora inequalis, H) Orthretum sabina, I) Hydrotea sp., J) Phaemicia sericata, K) Coccinela transversalis, L) Trigona sp,, M) Oxybelus sp., N) Delia sp. dan O) Bactrocera spp.

Kutu daun Aphis gossypii menyerang pada bagian bawah daun yang dapat menyebabkan keriting daun pada tanaman cabai sehingga tanaman akan menjadi layu, kering dan akhirnya mati (Gambar 9). 


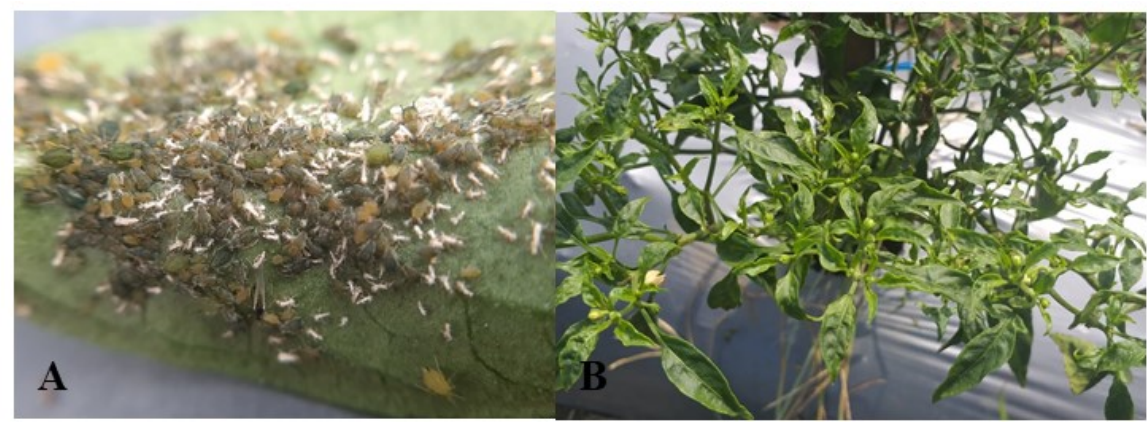

Gambar 9. Serangga hama kutu daun (Aphis gossypii) (A); Gejala keriting daun yang disebabkan oleh kutu daun (Aphis gossypii) (B).

Kutu kebul (Bemisia tabaci) yang dapat menyebabkan bercak kuning dan klorosis pada daun, disebabkan oleh rusaknya selsel dan jaringan daun akibat serangan pada fase nimfa dan imago, Sehingga dapat menghambat pertumbuhan tanaman, Kutu kebul juga diketahui berperan sebagai vektor penyakit salah satunya yakni Virus kuning pada tanaman cabai (Gambar 10).

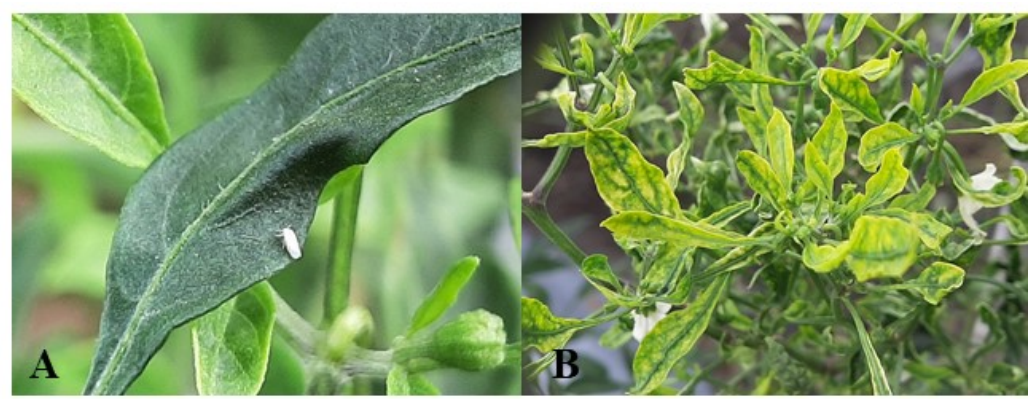

Gambar 10. Serangga hama kutu kebul (Bemisia tabaci) (A); Gejala virus kuning yang disebabkan oleh kutu kebul (Bemisia tabaci) (B).

Lalat buah biasanya menyerang pada buah yang berkulit tipis, dengan daging yang lunak, serangan lalat sering ditemukan pada buah yang hampir masak, dicirikan dengan daging buah

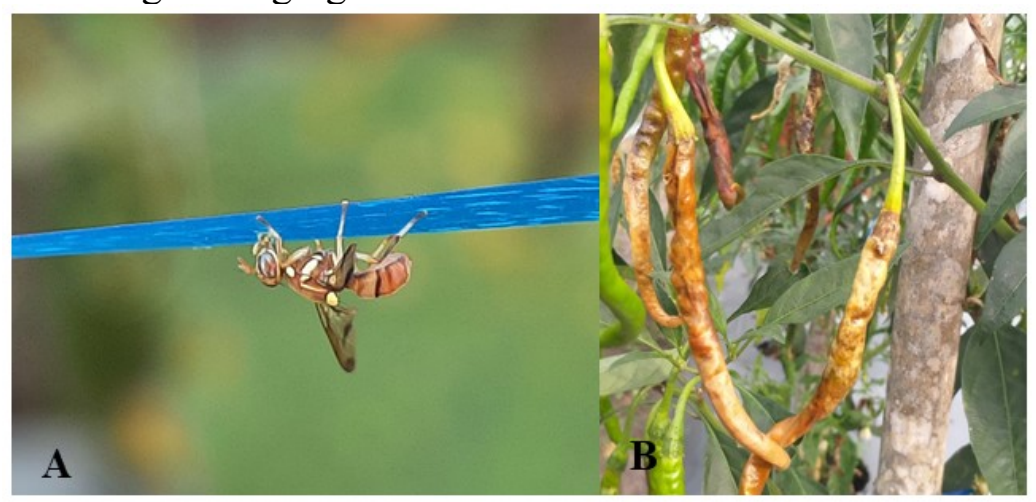

Gambar 11. Serangga hama lalat buah (Bactrocera spp.) (A); Gejala buah yang membusuk membusuk dan terdapat larva, Larva akan memakan daging buah sehingga buah menjadi busuk sebelum waktunya masak (Gambar 11).

\footnotetext{
yang disebabkan oleh lalat buah (B).
} 
Intensitas serangan Kutu daun (Aphis gossypii), Kutu kebul (Bemisia tabaci) dan Lalat buah (Bactrocera spp.) pada lahan petani cabai berbeda. Hal ini dikarenakan setiap serangga memiliki fase masing-masing dalam menyerang tanaman cabai (Gambar 12).

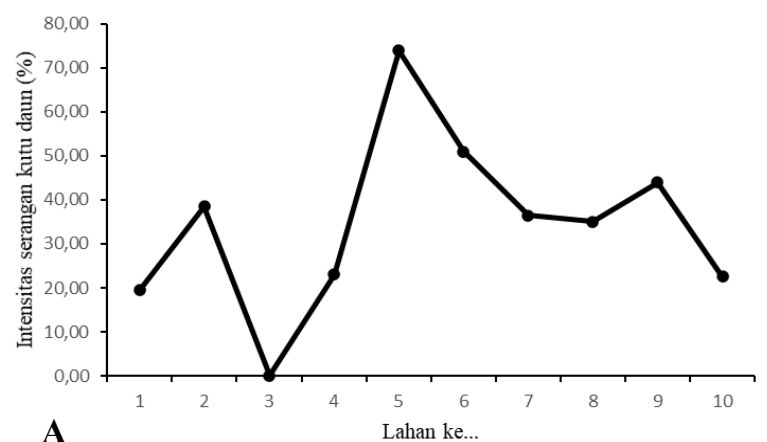

A
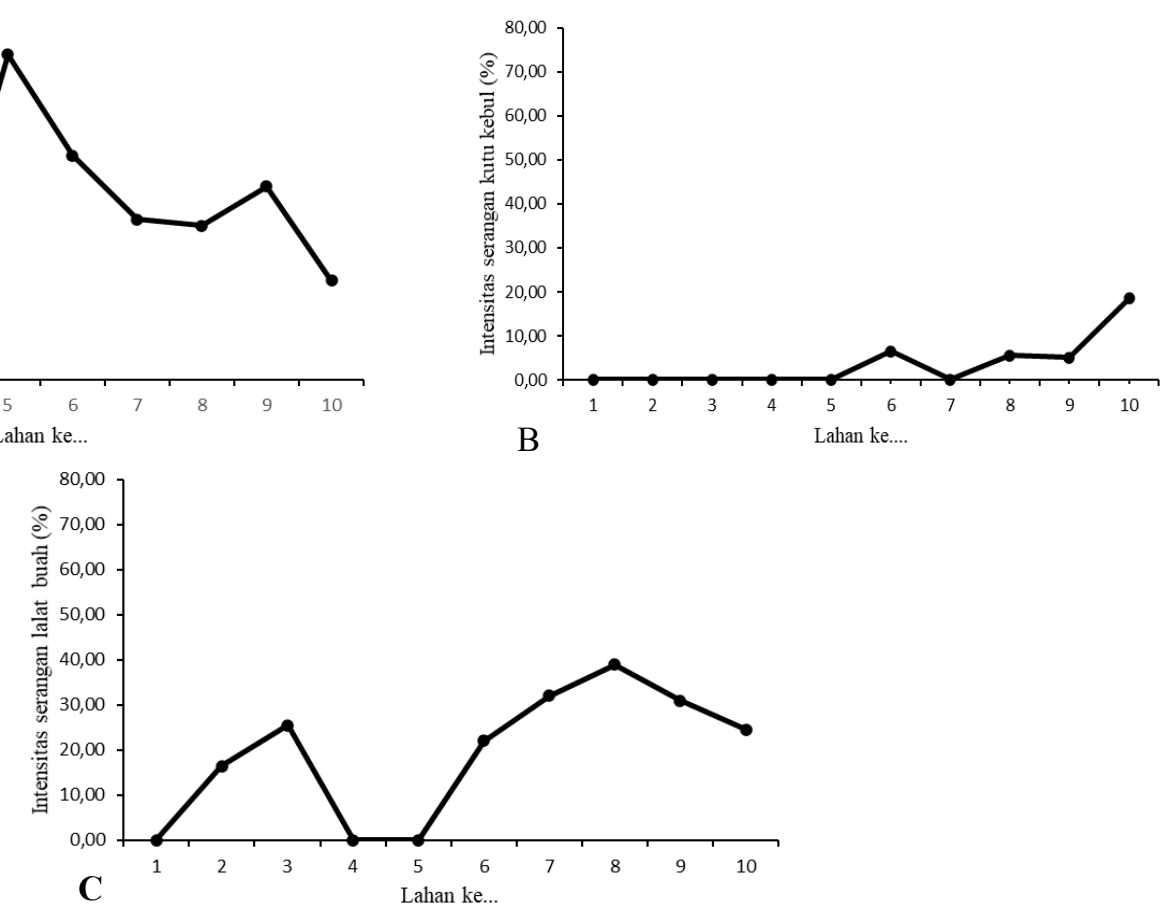

Gambar 12. Intensitas serangan hama Kutu daun (A), Kutu Kebul (B) dan Lalat buat (C) pada tanaman cabai di Desa Tanjung Pering.

Konsep Pengendalian Hama Terpadu yang digunakan untuk menekan suatu populasi hama serta untuk mendapatkan hasil produksi yang baik, Menurut Subagyo et al., (2017) pengendalian hama terpadu sendiri merupakan solusi yang tepat dalam mengatasi permasalahan petani karena PHT adalah perpaduan dari berbagai teknologi pengendalian yang serasi dengan mempertimbangkan berbagai aspek seperti ekonomi, ekologi dan sosial, sehingga ramah terhadap lingkungan. Berdasarkan hasil wawancara secara langsung didapatkan bahwa pengolahan lahan yang menggunakan konsep PHT meliputi kultur teknis, pengendalian mekanik dan kimiawi, Kultur teknis yang digunakan oleh petani di Desa Tanjung Pering berupa cara-cara bercocok tanam seperti menerapkan jarak tanam, yang dimana jarak tanam antar tanaman pada setiap petani bervariasi yaitu sekitar $40 \mathrm{~cm}$ sampai $60 \mathrm{~cm}$, Tujuan dari jarak tanam ini adalah supaya apabila jarak tanamnya terlalu rapat maka akan memudahkan hama dalam menyebar ke tanaman. Penggunaan varietas yang tahan juga merupakan salah satu konsep dari PHT secara kultur teknis, para petani di Desa Tanjung Pering menggunakan beberapa varietas diantaranya adalah Akar, Ketapi, Lolay, Electra dan Varietas Hibrida. 


\section{KESIMPULAN}

Keanekaragaman arthropoda pada lahan cabai secara visual dan menggunakan perangkap Pantrap serta Yellowstiky trap didapatkan tergolong rendah dan sedang. Arthropoda yang ditemukan di lapangan terdiri dari hama, predator, penyerbuk dan serangga decomposer. Nilai Indeks keragaman Shannon-Wiener serangga pada pertanaman cabai di Desa Tanjung Pering tergolong sedang dan merata karena nilainya kebanyakan mendekati 2,00. Nilai sebaran individu spesies serangga pada pertanaman cabai tergolong stabil karena nilainya mendekati 1,00 dan nilai Proporsi spesies yang mendominasi pada pertanaman cabai tergolong merata karena nilainya mendekati 1 maka hampir spesies yang ada mempunyai kelimpahan yang sama. Serangga hama yang menyerang tanaman cabai yaitu, Kutu daun (Aphis gossypii), kutu kebul (Bemisia tabaci) dan buah (Bactrocera spp.) dengan intensitas serangan yang berbeda-beda.

\section{UCAPAN TERIMA KASIH}

Program Studi Proteksi Tanaman, Jurusan Hama dan Penyakit Tumbuhan, Fakultas Pertanian, Universitas Sriwijaya dan Lembaga Penelitian dan Pengabdian Masyarakat Universitas Sriwijaya.

\section{DAFTAR PUSTAKA}

Agustinawati, Toana, H. M., dan Wahid, A. (2016). Keanekaragaman Arthropoda Permukaan Tanah pada Tanaman Cabai (Capsicum annum L.) dengan Sistem Pertanaman yang Berbeda Di Kabupaten Sigi. EJurnal Agrotekbis, 4(1), 8-15.

Anggraini, K. (2018). Pengaruh Populasi Kutu Daun pada Tanaman Cabai Besar ( Capsicum annuum L .) terhadap Hasil Panen. Jurnal
Agroekoteknologi Tropika, 7(1), 113-121.

Arsi dan Kemal, A. (2021). Pengaruh Kultur Teknis terhadap Serangan Hama Spodoptera litura pada Tanaman Cabai Merah (Capsicum annuum L.) di Desa Kerinjing Kecamatan Dempo Utara Kota Pagar Alam Provinsi Sumatera Selatan. Jurnal Planta Simbiosa, 3(1), 66-77.

Badan Pusat Statistik. (2015). Statistik Indonesia 2015. Jakarta.

BPS. (2020). "Bps File Produksi 2019 cabai." Sumsel.Bps.Go.Id. 2020.

Budiyani, N. K. dan Sukasana, I. W. (2020) Pengendalian Serangan Hama Lalat Buah pada Intensitas Kerusakan Buah Cabai Rawit (Capsicum frutescens L.) dengan Bahan Petrogenol. AGRICA, 2(1), 15-27.

Cahyono, D. B., Ahmad, H. dan Tolangara, A. R. (2018). Hama pada Cabai Merah. Techno: Jurnal Penelitian, 6(02), 18. https://doi.org/10.33387/tk.v6i02.56 5

Candra, Z., Kristiaga, J. dan Agastya, I. M. I. (2020). Kelimpahan Serangga Musuh Alami dan Serangga Hama Pada Ekosistem Tanaman Cabai Merah ( Capsicum annum L . ) pada Fase Vegetatif di Kecamatan Dau Kabupaten Malang. Jurnal Penelitian Pertanian Terapan, 20(3), 230-236.

Eliyatiningsih dan Mayasari, F. (2019). Efisiensi Penggunaan Faktor Produksi pada Usahatani Cabai Merah di Kecamatan Wuluhan Kabupaten Jember. Jurnal Agrica, 12(1), 7. https://doi.org/10.31289/agrica.v12i 1.2192

Harmana, S. B. dan Rahardjo, B. T. (2021).

Keanekaragaman Arthropoda pada Pertanaman Mentimun (Cucumis sativus L.) 
dengan Sistem PHT dan Konvensional Di Kecamatan Mantup, Lamongan. Jurnal Hama Dan Penyakit Tumbuhan, 9(1), 1-7. https://doi.org/10.21776/ub.jurnalhpt .2021 .009 .1 .1

Hasibun, S. (2020). Pengendalian Terpadu Hama pada Tanaman Cabai (Capsicum annum L.) dengan Menggunakan Perangkap Fluorense dan Berbagai Perangkap Warna. Asahan University Multidisciplinary National Seminar Proceedings, September, 1022-1033.

Hatta, H. dan Nursanty. (2020). Penentuan Produktivitas Daerah Kabupaten Terbaik sebagai Penghasil Tanaman Sayuran Cabai di Provinsi Sumatera Selatan Menggunakan Diagram Kartesius. Publikasi Penelitian Terapan Dan Kebijakan, 3(1), 26-33.

Intarti, D. Y., Kurniasari, I., dan Sudjianto, A. (2020). Efektivitas Agen Hayati Beauveria bassiana dalam Menekan Hama Thrips sp. pada Tanaman Cabai Rawit (Capcisum frutescens L.). Agrovigor: Jurnal Agroekoteknologi, 13(1), 10-15. https://doi.org/10.21107/agrovigor.v 13i1.5621

Jasridah, Rusdy, A. dan Hasnah, H. (2021). Komparasi Keanekaragaman Arthropoda Permukaan Tanah pada Komoditas Cabai Merah, Cabai Rawit dan Tomat. Jurnal Ilmiah Mahasiswa Pertanian, 6, 347-355.

Juniawan. (2020). Dinamika populasi Lalat Buah pada Tanaman Hortikultura. Jurnal ARGI Peat, 21(2), 96-103.

Magurran, A. E. (2014). Measuring Biological Diversity. In In Angewandte Chemie International Edition, 6(11), 951-952.Blackwell Publishing Company.

Manikome, N. (2018). Keragaman Jenis dan Populasi Serangga pada
Tanaman Cabai Di Wilayah Tobelo. Seri Ilmu-Ilmu Alam Dan Kesehatan, 2(2015), 69-77.

Nur, V., Subagyo, O., Suwito, A., Efendy, O., Kartina, T., Darmawan dan Rachmatiyah, R. (2017). Pengendalian Hama Terpadu Pada Tanaman Cabai Di Kecamatan Cikajang Kabupaten Garut : Permasalahan Dan Profil Petani. Fauna Indonesia, 16(2), 26-34.

Putra, I. L. I. dan Utami, L. B. (2020). Keanekaragaman Serangga Pengunjung Tanaman Cabai. Journal of Biology and Applied Biology, 3(2), 85-92.

Rante, C. S. dan Manengkey, G. S. J. (2017). Prefernsi Hama Thrips sp. (Thysanoptera: Thripidae) terhadap Perangkap Berwarna Pada Tanaman Cabai. Eugenia, 23(3), 113-119. https://doi.org/10.35791/eug.23.3.20 17.18963

Rante, C. S., dan Manengkey, G. S. J. (2018). Preferensi Hama Thrips sp. (Thysanoptera: Thripidae) terhadap Perangkap Berwarna pada Tanaman Cabai. Eugenia, 23(3), 113-119. https://doi.org/10.35791/eug.23.3.20 17.18963

Rizqullah, M. R. dan Syamsuddin, T. (2020). Analisis Pendapatan Usahatani Cabai Merah di Desa Talang Kemang Kecamatan Rantau Bayur Kabupaten Banyuasin Provinsi Sumatera Selatan. Jurnal Ilmu Pertanian Agronitas, 2(1), 54 62.

Sanjaya, Y. dan Dibiyantoro, A. L. H. (2012). Keragaman Serangga pada Tanaman Cabai (Capsicum annuum L.) yang Di beri Pestisida Sintetis Versus Biopestisida Racun LabaLaba (Nephila Sp.). Jurnal Hama Dan Penyakit Tumbuhan Tropika, 12(2), 192-199. https://doi.org/10.23960/j.hptt.21219 2-199

Sari, D. E., Mutmainna, I. dan Yustisia, 
D. (2020). Identifikasi Hama Lalat Buah (Dipter: Tephiritidae) Pada Beberapa Tanaman Hortikultura. Agrominasia, 5(1), 1-9.

Saroinsong, R. S. (2014). Inventarisasi Jenis-Jenis Hama pada Pertanaman Cabai (Capsicum annum L.) di Kelurahan Kakaskasen I Kota Tomohon. Cocos, 5(2), 0-7.

Setiawati, W., Sumarni, N., Koesandriani, Y., Hasyim, A., Uhan, T. dan Sutarya, R. (2013). Penerapan Teknologi Pengendalian Hama Terpadu pada Tanaman Cabai Merah untuk Mitigasi Dampak Perubahan Iklim. Jurnal Hortikultura, 23(2), 174-183.

Setiawati, W., Udiarto, B. dan Soetiarso, T. (2008). Pengaruh Varietas dan Sistem Tanam Cabai Merah terhadap Penekanan Populasi Hama Kutu Kebul. Jurnal Hortikultura, 18(1), 85349. https://doi.org/10.21082/jhort.v18n1 .2008.p

Solihin, A. P. (2020). Identifikasi dan Preferensi Lalat Buah (Bactrocera spp.) terhadap Estrak Serai (Andropogon nardus) dan Warna Perangkap pada Tanaman Cabai (Capsicum annum). Jurnal Agercolere, 2(2), 53-58. https://doi.org/10.37195/jac.v2i2.10 9

Sunarno. (2011). Ketertarikan Serangga Hama Lalat Buah terhadap Berbagai Papan Perangkap Berwarna sebagai Salah Satu Teknik Pengendalian Politeknik Perdamaian Halmahera. Jurnal Agroforestrl, VI(2), 129-134.

Susanto, A., Dana Permana, A., Hartati, S., Tohidin, T. dan Natalia Br. Saragih, D. (2021). Pengaruh Formulasi Metil Eugenol Block Plus terhadap Tangkapan Lalat Buah Bactrocera spp. pada tanaman cabai. Jurnal Entomologi Indonesia, 18(2), 93-101. https://doi.org/10.5994/jei.18.2.93
Yasurruni, K. (2018). Kelimpahan dan Keanekaragaman Arthropoda Permukaan Tanah pada Ekosistem Pertanaman Cabai Rawit (Capsicum frutescens L.) Di Kuripan Lombok Barat Abundance. Agroekoteknologi, 1-13.

Yulia, R., Susanna, S. dan Hasnah, H. (2021). Komparasi Keanekaragaman Serangga pada Tanaman Cabai Merah, Cabai Rawit Dan Tomat. Jurnal Ilmiah Mahasiswa Pertanian, 6(12), 338-346. 